\title{
Microbial helpers allow cyanobacteria to thrive in ferruginous waters
}

\section{Microbial helpers allow cyanobacteria to thrive in ferruginous waters}

$4{ }^{1}$ School of Earth and Atmospheric Sciences, Georgia Institute of Technology, Atlanta, GA

$5 \quad{ }^{2}$ School of Biological Sciences, Georgia Institute of Technology, Atlanta, GA

6 *Corresponding authors: nadia.szeinbaum@biology.gatech.edu; jennifer.glass@ eas.gatech.edu

7 Running title: Cyanobacterial fitness in early oceans

9 Acknowledgements. This research was funded by NASA Exobiology grant NNX14AJ87G,

10 NASA Astrobiology Institute grant 13-13NAI7_2-0027, and a NASA Astrobiology Postdoctoral

11 Fellowship to NS. We thank Jennifer Thweatt for advice on culturing Synechococcus sp. PCC

12 7002. We thank Amit Reddi for allowing us to use his plate reading spectrometer. We thank

13 Sommer Durham for technical assistance with the cytometer. We thank Patricia Sanchez-

14 Baracaldo and Manuel Kleiner for helpful discussions.

16 Competing Interests: The authors declare no competing interests. 


\section{Microbial helpers allow cyanobacteria to thrive in ferruginous waters}

\section{Abstract}

19 The Great Oxidation Event (GOE) was a rapid accumulation of oxygen in the atmosphere as a 20 result of the photosynthetic activity of cyanobacteria. This accumulation reflected the 21 pervasiveness of $\mathrm{O}_{2}$ on the planet's surface, indicating that cyanobacteria had become 22 ecologically successful in Archean oceans. Micromolar concentrations of $\mathrm{Fe}^{2+}$ in Archean oceans

23 would have reacted with hydrogen peroxide, a byproduct of oxygenic photosynthesis, to produce

24 hydroxyl radicals, which cause cellular damage. Yet cyanobacteria colonized Archean oceans 25 extensively enough to oxygenate the atmosphere, which likely required protection mechanisms 26 against the negative impacts of hydroxyl radical production in $\mathrm{Fe}^{2+}$-rich seas. We identify several 27 factors that could have acted to protect early cyanobacteria from the impacts of hydroxyl radical 28 production and hypothesize that microbial cooperation may have played an important role in 29 protecting cyanobacteria from $\mathrm{Fe}^{2+}$ toxicity before the GOE. We found that several strains of 30 facultative anaerobic heterotrophic bacteria (Shewanella) with ROS defense mechanisms 31 increase the fitness of cyanobacteria (Synechococcus) in ferruginous waters. Shewanella species

32 with manganese transporters provided the most protection. Our results suggest that a tightly 33 regulated response to prevent $\mathrm{Fe}^{2+}$ toxicity could have been important for the colonization of 34 ancient ferruginous oceans, particularly in the presence of high manganese concentrations, and 35 may expand the upper bound for tolerable $\mathrm{Fe}^{2+}$ concentrations for cyanobacteria. 


\section{Microbial helpers allow cyanobacteria to thrive in ferruginous waters}

\section{Introduction}

Earth's first biogeochemical cycles were driven by anaerobic microorganisms (Canfield et al., 2006; Martin et al., 2018). At around 2.3 Ga, the Great Oxidation Event (GOE) resulted in the initial oxygenation of the atmosphere and surficial biosphere, which ultimately led to the modern dominance of aerobic organisms on Earth's surface (Bar-On et al., 2018; Luo et al., 2016). Although biological $\mathrm{O}_{2}$ production was a prerequisite for the GOE (Haqq-Misra et al., 2011; Holland, 2002), oxygenic photosynthesis may have emerged in cyanobacteria hundreds of millions of years prior to the initial accumulation of $\mathrm{O}_{2}$ in Earth's atmosphere (Cardona et al., 2019; Lalonde and Konhauser, 2015; Ossa Ossa et al., 2018; Planavsky et al., 2014). The delay between the emergence of cyanobacterial $\mathrm{O}_{2}$ production and $\mathrm{O}_{2}$ accumulation in the atmosphere may have been modulated by geophysical drivers (Catling et al., 2001; Holland, 2009; Lee et al., 2016), but may also reflect the time required for metabolic innovations to appear in early cyanobacteria or for the emergence of ecological linkages with other microbes facilitating the success of cyanobacteria (Blank and Sanchez-Baracaldo, 2010; Johnston et al., 2009; Lyons et al., 2014; Ozaki et al., 2019). Understanding how cyanobacteria cooperated with other microbes to colonize the Earth's surface is thus essential to understand the ecology and tempo of the GOE.

The emergence of oxygenic photosynthesis in cyanobacteria occurred in the Archean (Chisholm, 2017; Kendall et al., 2010; Konhauser et al., 2011; Lalonde and Konhauser, 2015; Lyons et al., 2014; Olson et al., 2013; Planavsky et al., 2014; Reinhard et al., 2013b). The metabolic expansion of cyanobacteria before the GOE may reflect their transition from land to $\mathrm{Fe}^{2+}$-rich Archean oceans (Herrmann and Gehringer, 2019). This transition would have been physiologically challenging due to $\mathrm{Fe}^{2+}$ toxicity from its reactions with reactive oxygen species (ROS) produced during photosynthesis (Swanner et al., 2015a). Archean oceans likely contained tens to hundreds of micromolar $\mathrm{Fe}^{2+}$ within the ocean interior (Canfield, 2005; Derry, 2015; Drever, 1974; Holland, 1973; Song et al., 2017), which would have reacted rapidly in the surface ocean with $\mathrm{O}_{2}$ produced from photosynthesis and any hydrogen peroxide $\left(\mathrm{H}_{2} \mathrm{O}_{2}\right)$ from photochemical reactions between $\mathrm{O}_{2}$ and dissolved organic matter, as well as enzymes like superoxide dismutase (Hansel and Diaz, 2020; Zinser, 2018b). This $\mathrm{Fe}^{2+}$-driven reaction, known as the Fenton reaction, produces hydroxyl radicals (·OH; Eq. 1):

$$
\mathrm{H}_{2} \mathrm{O}_{2}+\mathrm{Fe}^{2+} \rightarrow \mathrm{Fe}^{3+}+\mathrm{OH}^{-}+\cdot \mathrm{OH}
$$




\section{Microbial helpers allow cyanobacteria to thrive in ferruginous waters}

Hydroxyl radicals cause cellular damage, especially to DNA (Imlay, 2003; Imlay, 2008).

67 Toxicity of $\mathrm{Fe}^{2+}$ may have prevented cyanobacteria from extensively colonizing Archean oceans

68 (Swanner et al., 2015a). Yet, cyanobacteria must have colonized vast areas of the ocean in order

69 to oxygenate the atmosphere. This paradox can be resolved by considering that anti-oxidants

70 such as elevated dissolved manganese $\left(\mathrm{Mn}^{2+}\right)$ and ancient $\mathrm{Mn}$-based catalases may have

71 protected ancient cyanobacteria against ROS toxicity (Fischer et al., 2016).

72 Here, we test the hypothesis that heterotrophic microbial "helpers" may have protected

73 cyanobacteria from ROS produced by Fenton chemistry in Archean oceans, thereby increasing

74 cyanobacterial fitness and enabling their ecological success. Such microbial cooperation is

75 common among modern cyanobacteria and heterotrophic proteobacteria (Christie-Oleza et al.,

76 2017; Morris et al., 2011; Morris et al., 2008; Zinser, 2018a), whose intimate relationship is

77 evidenced by extensive horizontal gene transfer (Ben Said and Or, 2017; Braakman et al., 2017;

78 Goldenfeld and Woese, 2011). At the time of the GOE, many bacterial lineages, including

79 Proteobacteria, had already diversified (Battistuzzi et al., 2004; Cavalier-Smith, 2006a; Cavalier-

80 Smith, 2006b), which would have increased the phenotypic pool available for cooperation.

81 Including microbial cooperation as an ecological mechanism in models of early Earth's

82 ecological history might provide a more realistic picture of the ancient interactions that

83 ultimately led to the GOE.

84 We explored whether the presence of "helper" heterotrophic proteobacteria leads to

85 increased fitness of cyanobacteria in ferruginous conditions. For a model cyanobacterium, we

86 chose Synechococcus sp. PCC 7002 (hereafter Synechococcus), which was previously shown to

87 experience $\mathrm{Fe}^{2+}$ toxicity at $>100 \mu \mathrm{M} \mathrm{Fe}^{2+}$ associated with increased intracellular ROS production

88 (Swanner et al., 2015a). As potential "helper" bacteria, we chose Shewanella, facultative

89 anaerobic gammaproteobacteria that can survive $\mathrm{O}_{2}$ intrusions in the presence of high $\mathrm{Fe}^{2+}$ using

90 diverse $\mathrm{H}_{2} \mathrm{O}_{2}$-scavenging enzymes (Jiang et al., 2014; Mishra and Imlay, 2012; Sekar et al.,

91 2016). Experimental conditions simulated a pre-GOE illuminated ferruginous surface ocean

92 overlain by a $\mathrm{CO}_{2-}$ and $\mathrm{H}_{2}$-rich anoxic atmosphere. We found that several Shewanella species

93 allowed Synechococcus to grow in ferruginous conditions that significantly impaired growth of

94 Synechococcus monocultures. The "helper" Shewanella strains all contained the ability to

95 actively uptake dissolved manganese $\left(\mathrm{Mn}^{2+}\right)$ via the natural resistance-associated macrophage

96 protein (NRAMP) family $\mathrm{MntH} \mathrm{Mn}^{2+}$ transporter, a strategy that has previously been shown to 


\section{Microbial helpers allow cyanobacteria to thrive in ferruginous waters}

correlate with ROS survival (Daly et al., 2004). Our results stress the importance of considering microbial cooperation and alternative ROS strategies, such as manganese protection, in models of early Earth microbial ecology.

\section{Results}

Cyanobacteria growth is impaired in ferruginous conditions and is restored in the presence of some proteobacteria. We found that Synechococcus growth in the presence of elevated $\mathrm{Fe}^{2+}$ improved (to a varying degree) in the presence of all Shewanella spp. tested. In monoculture, Synechococcus had similar growth rate and yield at 25 and $500 \mu \mathrm{M} \mathrm{Fe}^{2+}$, but a longer lag period at $500 \mu \mathrm{M} \mathrm{Fe}^{2+}(\sim 2$ days $)$ than at $25 \mu \mathrm{M} \mathrm{Fe}^{2+}(\sim 1$ day; Fig. 1A). At $1000 \mu \mathrm{M}$ $\mathrm{Fe}^{2+}$, Synechococcus growth was significantly impaired in monoculture, reaching only $10 \%$ the cell density of cultures with 25 and $500 \mu \mathrm{M} \mathrm{Fe}^{2+}$ (Fig. 1A). In contrast, Synechococcus growth was minimally suppressed in the presence of high $\mathrm{Fe}^{2+}$ when grown in co-culture with Shewanella baltica OS-155, although the initial lag period was extended (Fig. 1B). In the presence of Shewanella algae MN-01 (Fig. 1C) and Shewanella loihica PV-4 (Fig. 1D), Synechococcus growth was slightly suppressed at 500 and $1000 \mu \mathrm{M} \mathrm{Fe}^{2+}$. Other than an extended lag phase, Shewanella algae BrY (Fig. 1E) and Shewanella oneidensis MR-1 (Fig. 1F) had minimal influence on Synechococcus growth, compared to the monoculture (Fig. 1A), in all three $\mathrm{Fe}^{2+}$ treatments. Although difficult to quantify due to spectral interference of $\mathrm{Fe}$ (III) oxide particles, Shewanella cell numbers declined throughout the experiment (data not shown).

The best proteobacterial helpers are the least $\mathrm{H}_{2} \mathrm{O}_{2}$ sensitive, and the best $\mathrm{H}_{2} \mathrm{O}_{2}$ scavengers. We measured growth and $\mathrm{H}_{2} \mathrm{O}_{2}$ scavenging rates of Shewanella spp. in the presence of varying $\mathrm{H}_{2} \mathrm{O}_{2}$. S. baltica OS-155 was the least sensitive to $\mathrm{H}_{2} \mathrm{O}_{2}$ (Fig. 2A). S. algae $\mathrm{MN}-01$ (Fig. 2B), S. loihica PV-4 (Fig. 2C), and S. algae BrY (Fig. 2D) were moderately sensitive to $\mathrm{H}_{2} \mathrm{O}_{2}$. S. oneidensis MR-01 was the most sensitive to $\mathrm{H}_{2} \mathrm{O}_{2}$ (Fig. 2D). Along with being most $\mathrm{H}_{2} \mathrm{O}_{2}$ tolerant, S. algae MN-01 and S. baltica OS-155 had the highest rates of $\mathrm{H}_{2} \mathrm{O}_{2}$ scavenging activity, followed by S. algae BrY (Fig. 3). S. loihica PV-4 and S. oneidensis MR-1 had the lowest $\mathrm{H}_{2} \mathrm{O}_{2}$ scavenging rates (Fig. 3).

Manganese may protect cyanobacteria from $\mathrm{Fe}^{2+}$ toxicity. To test whether $\mathrm{Mn}^{2+}$ can protect cyanobacteria from $\mathrm{Fe}^{2+}$ toxicity, we grew Synechococcus PCC 7002 (four replicates per treatment) under anoxic conditions with the addition of $1 \mathrm{mM} \mathrm{Fe}{ }^{2+}$ and/or $1 \mathrm{mM} \mathrm{Mn}{ }^{2+}$. Cells 


\section{Microbial helpers allow cyanobacteria to thrive in ferruginous waters}

128 with $1 \mathrm{mM} \mathrm{Mn}^{2+}$ grew similarly to the controls (Fig. 4). The A+ medium contained background 129 concentrations of $\sim 140 \mu \mathrm{M} \mathrm{Fe}^{2+}$ and $\sim 220 \mu \mathrm{M} \mathrm{Mn}^{2+}$. No growth occurred with $1 \mathrm{mM} \mathrm{Fe}^{2+}$. Red

$130 \mathrm{Fe}(\mathrm{III})$ oxide particles indicated that $\mathrm{Fe}^{2+}$ had been oxidized and precipitated, as observed by

131 Swanner et al. (2015b). Treatments with $1 \mathrm{mM} \mathrm{Fe}^{2+}$ and $1 \mathrm{mM} \mathrm{Mn}{ }^{2+}$ resembled $1 \mathrm{mM} \mathrm{Fe}^{2+}$

132 treatments for approximately the first week. Between 4-13 days, two out of four of the $\mathrm{Fe}^{2+}$ and

$133 \mathrm{Mn}^{2+}$ treatments grew to maximal $\mathrm{OD}_{750}$. These results show that $1 \mathrm{mM} \mathrm{Mn}^{2+}$ is not toxic to

134 cyanobacteria and may in fact aid in the survival of cyanobacteria $\mathrm{Fe}^{2+}$ toxicity, after an

135 acclimation period. The mechanism that rescued growth of two out of four of the cultures to 136 grow in the presence of high $\mathrm{Fe}^{2+}$ after an extended lag phase remains unknown.

137 The best proteobacterial helpers encode additional genes for $\mathrm{H}_{2} \mathrm{O}_{2}$ degradation.

138 Synechococcus PCC 7002's susceptibility to $\mathrm{Fe}^{2+}$ toxicity is consistent with the limited number

139 of catalase genes in its genome; it encodes cytoplasmic KatG but not periplasmic KatE (Table

140 1). Without KatE to scavenge $\mathrm{H}_{2} \mathrm{O}_{2}$ in the periplasm, $\mathrm{H}_{2} \mathrm{O}_{2}$ can react with $\mathrm{Fe}^{2+}$ to generate $\cdot \mathrm{OH}$

141 intracellularly (Eq. 1). Like Synechococcus PCC 7002, most marine cyanobacteria are KatE-

142 negative; a BLAST search of cyanobacterial genomes in NCBI recovered KatE catalase

143 homologs almost exclusively in freshwater and soil cyanobacteria (Table S1).

144 To identify genes in Shewanella that may have helped alleviate $\mathrm{Fe}^{2+}$ toxicity to

145 Synechococcus, we compared the genomes of the Shewanella strains in our experiments.

146 Notably, several Shewanella spp. contained catalases predicted to have multiple cellular

147 locations, as previously observed for other microbial catalases (Hanaoka et al., 2013). Overall,

148 the genomic inventory of catalase and peroxidase proteins was generally similar between the

149 more protective and less protective species (Table 1), suggesting (an)other mechanism(s) for

150 ROS survival. We found 52 proteins in the best helpers (OS-155 and MN-01) that were not

151 present in the other Shewanella strains, including genes for flagella, phenazine biosynthesis, and

152 transporters (Table S3). Flagella may be involved in the ROS-stress response in eukaryotes

153 (Hajam et al., 2017), but their connection to ROS protection in bacteria, if any, is unknown.

154 Phenazines are known to produce oxidative stress (Imlay, 2013), and can also mediate

155 extracellular redox transfers (Hernandez et al., 2004; Wang and Newman, 2008), but are unlikely

156 to be responsible for the protective effect because Synechococcus PCC 7002 also possesses the

$157 \quad p h z F$ gene for phenazine synthesis. 


\section{Microbial helpers allow cyanobacteria to thrive in ferruginous waters}

The high $\mathrm{H}_{2} \mathrm{O}_{2}$ sensitivity of $S$. oneidensis $\mathrm{MR}-1$, which contains a similar repertoire of $\mathrm{H}_{2} \mathrm{O}_{2}$-scavenging enzymes as less $\mathrm{H}_{2} \mathrm{O}_{2}$-sensitive Shewanella spp., is thought to be due to its inability to actively transport and accumulate intracellular $\mathrm{Mn}^{2+}$ (Daly et al., 2004; Jiang et al., 2014). We surmised that differences in ROS scavenging rates between Shewanella strains may

162 be due to differences in acquisition of $\mathrm{Mn}^{2+}$. We found $\mathrm{MntH} \mathrm{Mn}^{2+}$ transporters in the genomes

163 of the three top Shewanella helpers: OS-155, MN-01, and PV-4 (Table 1). Shewanella BrY and 164 MR-1 lacked characterized $\mathrm{Mn}^{2+}$ transporters. Synechococcus PCC 7002 contained genes for the 165 ATP-binding cassette $(\mathrm{ABC})$ family $\mathrm{Mn}^{2+}$ transporters MntABCD and SitABCD transporter instead of MntH.

\section{Discussion}

The rise of $\mathrm{O}_{2}$ and ROS from oxygenic photosynthesis would have severely stressed strictly anaerobic microbes (Khademian and Imlay, 2020), resulting in what was perhaps Earth's

171 first mass extinction. Experiments demonstrating that catalase-negative cyanobacteria 172 (Synechococcus PCC 7002) grew poorly in $>100 \mu \mathrm{M} \mathrm{Fe}^{2+}$ led to the idea that $\mathrm{Fe}^{+}$-rich oceans 173 would have slowed cyanobacterial colonization of the ocean surface and possibly delayed global 174 oxygenation (Swanner et al., 2015a). Our study confirms the previous finding that 175 Synechococcus PCC 7002, originally isolated from marine mud, has impaired growth when $\mathrm{Fe}^{2+}$ 176 was $180 \mu \mathrm{M}$ and higher. We show that this $\mathrm{Fe}^{2+}$ toxicity can be alleviated by some strains of 177 "helper" Shewanella spp., with the best protection afforded by Shewanella strains possessing the 178 most varied sets of ROS-defense pathways (e.g. catalases, MntH transporters) and the highest 179 rates of $\mathrm{H}_{2} \mathrm{O}_{2}$ degradation. Likely, this protection was afforded by Shewanella scavenging $\mathrm{H}_{2} \mathrm{O}_{2}$ 180 prior to its reaction with $\mathrm{Fe}^{2+}$, thereby decreasing the production of damaging hydroxyl radicals.

Thus, our findings align with previous findings (Brown et al., 2010; Ward et al., 2019)

182 that cyanobacterial colonization of early oceans would not have been hampered by micromolar

$183 \mathrm{Fe}^{2+}$ concentrations, if $\mathrm{Mn}^{2+}$-transporting and $\mathrm{H}_{2} \mathrm{O}_{2}$-scavenging genes were present within the 184 microbial communal gene pool. Early marine cyanobacteria, like modern terrestrial 185 cyanobacteria, likely had myriad protections against $\mathrm{Fe}^{2+}$ and/or may have benefitted from the 186 presence of co-existing "helper" bacteria to cope with the harmful byproducts produced by their 187 own metabolism in a ferruginous ocean, which would have later been lost due to genome 188 streamlining in marine cyanobacteria. 


\section{Microbial helpers allow cyanobacteria to thrive in ferruginous waters}

Catalase-based protection. The ubiquity of catalase genes in the genomes of all the Shewanella strains we studied suggests that catalase accounts for the background protection

191 provided by all Shewanella spp. tested. The enhanced protection provided by Shewanella spp.

192 with similar catalase inventories implies that a mechanism other than catalase was likely at play,

193 presumably at the level of gene expression. This process may also be related to the centralized

194 regulation of $\mathrm{H}_{2} \mathrm{O}_{2}$-related genes in Shewanella spp. In S. oneidensis MR-1, the transcriptional

195 regulator OxyR is key for suppression of Fenton chemistry by derepression of KatE and Dps

196 (Jiang et al., 2014; Wan et al., 2018) whereas $\mathrm{H}_{2} \mathrm{O}_{2}$-based regulation is performed by multiple

197 regulators (including PerR) in Synechococcus PCC 7002 and other cyanobacteria (Latifi et al., 198 2009).

199 A protective effect of proteobacterial catalase has previously been observed for the 200 marine cyanobacterium Prochlorococcus, which grows in symbiosis with the 201 gammaproteobacterium Alteromonas (Biller et al., 2016; Morris et al., 2011; Morris et al., 2008).

202 (For more examples of microbe-microbe $\mathrm{H}_{2} \mathrm{O}_{2}$ protection, see review by Zinser (2018a).) Yet, 203 unlike those long-lived catalase-based symbioses, the presence of Shewanella in our co-cultures 204 was ultimately transient. A transient cooperative interaction can be a natural consequence of the 205 dynamics of public goods between microbial groups (Corno et al., 2013; Rodríguez Amor and 206 Dal Bello, 2019), when the members of the population that provide the extracellular "public 207 good" are at a fitness disadvantage by providing a costly product that nonproducers use (Cremer 208 et al., 2019; Özkaya et al., 2017). In our system, Synechococcus gained the fitness advantage of 209 protection from $\mathrm{Fe}^{2+}$ toxicity at the expense of Shewanella, whose population was eliminated 210 from the system as Synechococcus grew. Indeed, previous attempts to co-culture Shewanella 211 with cyanobacteria with $\sim 15 \mu \mathrm{M} \mathrm{Fe}^{2+}$, resulted in cyanobacterial dominance, with Shewanella's 212 growth yield compromised by the presence of Synechococcus sp. 7002 even in the presence of 213 organic carbon (Beliaev et al., 2014).

214 Thus, our co-culture experiments illustrate that cyanobacteria can benefit from the 215 presence of "helper" proteobacteria under ferruginous conditions. This protection may have been 216 one of the ways that cyanobacteria were able to cope with the harmful byproducts produced by 217 their own metabolism as they incipiently colonized a ferruginous ocean, which would have no 218 longer been necessary once cyanobacteria increased in numbers and seawater $\mathrm{Fe}^{2+}$ concentrations 219 dropped. The precise levels of dissolved $\mathrm{O}_{2}$ prevailing on different spatial scales in the surface 


\section{Microbial helpers allow cyanobacteria to thrive in ferruginous waters}

ocean prior to the GOE are not fully known. However, there is theoretical evidence to suggest that dissolved $\mathrm{O}_{2}$ would have been locally more than sufficient to support aerobic bacterial respiration (Olson et al., 2013; Reinhard et al., 2013a).

Manganese to the rescue. One of the genes regulated by $\mathrm{OxyR}$ is the $\mathrm{Mn}^{2+}$ transporter $\mathrm{MntH}$, which is used for accumulation of intracellular manganese $\left(\mathrm{Mn}^{2+}\right)$ as a potent ROS detoxification method (Anjem et al., 2009; Chen et al., 2008; Kehres et al., 2002). Unlike Fe ${ }^{2+}$, $\mathrm{Mn}^{2+}$ does not undergo Fenton-type reactions. Instead, $\mathrm{Mn}^{2+}$ has strong antioxidant properties (Cheton and Archibald, 1988) and is highly effective at protecting against $\mathrm{H}_{2} \mathrm{O}_{2}$-induced oxidative stress through multiple mechanisms (Aguirre and Culotta, 2012; Hansel, 2017; Horsburgh et al., 2002; Latour, 2015; Papp-Wallace and Maguire, 2006). $\mathrm{Mn}^{2+}$-carbonate and $\mathrm{Mn}^{2+}$-phosphate complexes can chemically disproportionate $\mathrm{H}_{2} \mathrm{O}_{2}$ (Archibald and Fridovich, 1982; Barnese et al., 2012; Stadtman et al., 1990). $\mathrm{Mn}^{2+}$-containing catalase, a very ancient member of the ferritin superfamily, detoxifies $\mathrm{H}_{2} \mathrm{O}_{2}$ (Klotz and Loewen, 2003; Zamocky et al., 2008). Under $\mathrm{H}_{2} \mathrm{O}_{2}$ stress, OxyR facilitates $\mathrm{Mn}^{2+}$ replacement of $\mathrm{Fe}^{2+}$ in ROS-sensitive enzymes, preventing their inactivation by Fenton chemistry (Anjem et al., 2009; Smethurst et al., 2020; Sobota and Imlay, 2011).

MntH transporters were found in the most protective Shewanella strains, but not in Synechococcus PCC 7002 (which instead encodes two ABC-type $\mathrm{Mn}^{2+}$ transporters) nor in the less protective Shewanella spp. (Table S1). In monocultures, the rescued growth of Synechococcus PCC 7002 in two out of four of high $\mathrm{Fe}^{2+}$ treatments with $\mathrm{Mn}^{2+}$ was likely related to the antioxidant properties of $\mathrm{Mn}^{2+}$, although the details of the protective mechanism, chemical or enzymatic, await further study. Our findings generally support the hypothesis that elevated seawater $\mathrm{Mn}^{2+}$ in early Earth environments ( 5-120 $\mu \mathrm{M}$; Holland, 1984; Johnson et al., 2016; Komiya et al., 2008; Liu et al., 2020) played a role in protecting marine cyanobacteria from $\mathrm{Fe}^{2+}$ toxicity (Fischer et al., 2016).

Modern microbial models for ancient physiologies. The choice of a model cyanobacterium for physiological experiments applicable to the Precambrian oceans is of great importance (Hamilton, 2019; Hamilton et al., 2016). Many terrestrial cyanobacteria thrive under the $10-100 \mu \mathrm{M} \mathrm{Fe}^{2+}$ concentrations predicted for Archean oceans (Brown et al., 2005; Ionescu et al., 2014; Ward et al., 2019; Ward et al., 2017) and either possess multiple catalases (Table S1) and/or have novel defense mechanisms such as intracellular iron precipitation (Brown et al., 


\section{Microbial helpers allow cyanobacteria to thrive in ferruginous waters}

2010). In contrast, modern marine cyanobacteria (e.g. Prochlorococcus) tend to be genetically streamlined for specific modern oceanographic provinces (Partensky and Garczarek, 2010), which are extremely $\mathrm{Fe}^{2+}$-poor compared to modern terrestrial and ancient ecosystems.

The closest modern descendants of the ancestral cyanobacteria that evolved into modern marine plankton cyanobacteria are filamentous non-heterocystous Synechococcales (SánchezBaracaldo, 2015; Sánchez $\square$ Baracaldo and Cardona, 2020). KatG was likely present in ancestors of marine cyanobacteria (Bernroitner et al., 2009; Zamocky et al., 2012), whereas KatE was likely horizontally transferred from Proteobacteria and Planctomycetes to some cyanobacterial linages (e.g. Nostocales; Zamocky et al., 2012). Synechococcus PCC 7002 lacks $\mathrm{Mn}^{2+}$-catalase, which is widespread in terrestrial cyanobacteria (Ballal et al., 2020; Banerjee et al., 2012; Bihani et al., 2016; Chakravarty et al., 2016; Chen et al., 2020) (Table S1) and was likely present in early cyanobacterial lineages (Klotz and Loewen, 2003; Zamocky et al., 2012).

Previous genetic studies of $\mathrm{Fe}^{2+}$-induced oxidative stress have studied cyanobacteria that cannot cope with high $\mathrm{Fe}^{2+}$ and $\mathrm{H}_{2} \mathrm{O}_{2}$, e.g. Synechocystis PCC 6803 (Li et al., 2004; Shcolnick et al., 2009) in monoculture. In nature, $\mathrm{ROS}$ and $\mathrm{O}_{2}$ cycling are communal processes. Thus, models that include shared mechanisms of survival are important to consider on the early Earth, particularly as gene pools were more limited and were in the process of expansion. We advocate for future studies on more deeply branching cyanobacterial species with additional ROS defense mechanisms and encourage more explicit incorporation of microbial interactions in large-scale models of biogeochemical cycling on the ancient Earth.

\section{Materials and Methods}

Bacterial strains. Synechococcus sp. PCC 7002 was ordered from the Pasteur Culture collection of Cyanobacteria. Shewanella oneidensis MR-1 and Shewanella algae BrY were kind gifts from the lab of Dr. Thomas DiChristina (Georgia Institute of Technology). Shewanella loihica PV-4 was a kind gift from Dr. Jeffrey Gralnick (University of Minnesota).

Experimental setup and growth conditions. Synechococcus sp. PCC 7002 was grown in serum bottles containing modified A+ medium (Stevens Jr. et al., 1973) with $10 \mathrm{~g} \mathrm{~L}^{-1} \mathrm{NaCl}$, TRIS buffer ( $\mathrm{pH}$ 7.2), and $10 \mathrm{mM} \mathrm{NH}_{4}{ }^{+}$as the nitrogen source. Shewanella spp. were grown overnight in lysogeny broth (LB, $10 \mathrm{~g} \mathrm{~L}^{-1} \mathrm{NaCl}, 10 \mathrm{~g} \mathrm{~L}^{-1}$ tryptone, $5 \mathrm{~g} \mathrm{~L}^{-1}$ yeast extract) and transferred into serum bottles containing modified $\mathrm{A}+$ medium with amino acids $\left(20 \mathrm{mg} \mathrm{L}^{-1} \mathrm{~L}\right.$ - 


\section{Microbial helpers allow cyanobacteria to thrive in ferruginous waters}

282 serine, $20 \mathrm{mg} \mathrm{L}^{-1} \mathrm{~L}$-arginine, and $20 \mathrm{mg} \mathrm{L}^{-1} \mathrm{~L}$-glutamic acid), $20 \mathrm{mM}$ lactate as electron donor, 283 and $20 \mathrm{mM}$ fumarate as electron acceptor. Bottles were flushed with $90 \% \mathrm{~N}_{2} / 10 \% \mathrm{CO}_{2}$ and 284 opened inside an anoxic chamber $\left(5 \% \mathrm{CO}_{2} / 4 \% \mathrm{H}_{2} / 91 \% \mathrm{~N}_{2}\right)$. Cultures were washed with anoxic $285 \mathrm{~A}+$ medium and combined at optical density of $600 \mathrm{~nm}\left(\mathrm{OD}_{600}\right)=0.01$. Co-cultures were grown 286 in triplicate in $10 \mathrm{~mL}$-well tissue culture plates inside the anoxic chamber $\left(5 \% \mathrm{CO}_{2} / 4 \% \mathrm{H}_{2} / 91 \%\right.$ $287 \mathrm{~N}_{2}$ ). Cultures were mixed daily by gentle pipetting $\sim 50 \%$ of the volume three times in order to 288 resuspend cells and particulate Fe(III) oxides; if not mixed regularly, PCC 7002 would grow at 289 the bottom of the well. Light was provided with a fluorescent light in a 12:12 light:dark timercontrolled cycle. $\mathrm{FeCl}_{2}$ was added at a final concentration of 25, 500, or $1000 \mu \mathrm{M}$.

Cyanobacterial quantification by flow cytometry. Cell numbers of Synechococcus sp. PCC 7002 were quantified in an LSR Fortessa flow cytometer using FACSDiva ${ }^{\mathrm{TM}}$ (BD 293 Biosciences, CA). At each time point, $200 \mu \mathrm{L}$ of culture was loaded into a 96-well plate inside 294 the anoxic chamber, covered in parafilm to minimize $\mathrm{Fe}^{2+}$ oxidation, transported to the 295 cytometer, and mixed twice in the cytometer. Samples $(10 \mu \mathrm{L})$ were injected and run at a rate of $2960.5 \mu \mathrm{L} \mathrm{s}^{-1}$. Cyanobacteria were detected by phycocyanin/chlorophyll autofluorescence using blue 297 (488 nm) and yellow-green lasers (561 nm) measured at 655-684 nm (Hill et al., 2017). 298 Optimization and calibration of the quantification parameters were achieved using yellow-green $2991 \mu \mathrm{m}$ microspheres (441/485 ex/em; Polysciences, PA). Live cyanobacteria were also quantified 300 using Syto9 using FITC filters. Events above the thresholds of PerCP and FITC were considered 301 live cyanobacteria. Propidium iodide could not be used to identify 'dead' cyanobacteria, as the 302 emission spectra overlapped with that of their autofluorescence. Due to spectral overlap with iron 303 particles, Shewanella cells could not be accurately quantified by cytometry.

$304 \mathrm{H}_{2} \mathrm{O}_{2}$ resistance assays. Six Shewanella strains were incubated in 96-well plates with 305 minimal M1 media (Myers and Nealson, 1988) with lactate $(10 \mathrm{mM})$ or acetate $(10 \mathrm{mM})$ as 306 electron donor under oxic conditions. Growth was monitored periodically (every 1-2 hours) by $307 \mathrm{OD}_{600}$ in a spectrophotometer with plate-reading capacity (Tecan, Switzerland). Hydrogen 308 peroxide was added after an initial period of growth for 4 hours, at a final concentration of 10, $30925,50,100$, or $250 \mu \mathrm{M}$, after which growth continued to be monitored.

$310 \boldsymbol{H}_{2} \boldsymbol{O}_{2}$ scavenging assays. We compared the abilities of the Shewanella spp. to remove $311 \mathrm{H}_{2} \mathrm{O}_{2}$ from their environment in cell suspensions. Strains were seeded in lysogeny broth (LB, 10 $312 \mathrm{~g} \mathrm{~L}^{-1} \mathrm{NaCl}, 10 \mathrm{~g} \mathrm{~L}^{-1}$ tryptone, $5 \mathrm{~g} \mathrm{~L}^{-1}$ yeast extract, Sigma-Aldrich) at $30^{\circ} \mathrm{C}$ with shaking 


\section{Microbial helpers allow cyanobacteria to thrive in ferruginous waters}

313 overnight, harvested by centrifugation at 12,300 x g, washed, and transferred into minimal M1

314 medium amended with $20 \mathrm{mM}$ lactate at $\mathrm{OD}_{600}=0.02$. Cells were incubated at $30^{\circ} \mathrm{C}$ with

315 shaking until harvesting at mid-log phase $\left(\mathrm{OD}_{600}=0.15-0.35\right)$, washed twice with minimal

316 medium, then inoculated at $\mathrm{OD}_{600}=0.05$ into a 24 -well plate holding $2 \mathrm{~mL}$ minimal M1 medium

317 amended with $20 \mathrm{mM}$ lactate and various concentrations of $\mathrm{H}_{2} \mathrm{O}_{2}(0-5000 \mu \mathrm{M})$. Samples were

318 collected every 3-5 minutes and analyzed immediately for exogenous $\mathrm{H}_{2} \mathrm{O}_{2}$ using the resorufin-

319 horseradish peroxidase colorimetric assay (Zhou et al., 1997). Plates were incubated under oxic

320 conditions at room temperature with shaking for the duration of the experiment (30-200

$321 \mathrm{~min}$ ). $\mathrm{H}_{2} \mathrm{O}_{2}$ disappearance followed an exponential decay (Eq. 2). First-order apparent rate

322 constants (k) were obtained by plotting the data as shown in Eq. 3, where k is the slope of the

323 graph with $\ln \left[\mathrm{H}_{2} \mathrm{O}_{2(\mathrm{t}=0)} / \mathrm{H}_{2} \mathrm{O}_{2(\mathrm{t}=\mathrm{n})}\right]$ on the $\mathrm{y}$-axis and time on the $\mathrm{x}$-axis.

$$
\mathrm{H}_{2} \mathrm{O}_{2(\mathrm{t}=\mathrm{n})}=\mathrm{H}_{2} \mathrm{O}_{2(\mathrm{t}=0)} \mathrm{e}^{-\mathrm{kt}}
$$

Unique proteins. Proteins present in Shewanella algae MN-01 and Shewanella baltica

327 OS155 and absent in Shewanella algae BrY, Shewanella oneidensis MR-1, and Shewanella

328 loihica PV-4 were identified using the Protein Families tool in PATRIC using three protein

329 family databases: PATRIC cross-genus families (PGfams), PATRIC genus-specific families 330 (PLfams), and FIGfam.

332 Synechococcus PCC 7002 growth with and without $1 \mathrm{mM} \mathrm{Fe} \mathrm{Fe}^{2+}$, Synechococcus was grown in 333 modified A+ medium containing $82 \mathrm{mM}$ bicarbonate in Hungate tubes with bromobutyl rubber 334 stoppers containing $95 \% \mathrm{~N}_{2} / 5 \% \mathrm{H}_{2}$ headspace with constant shaking at $200 \mathrm{rpm}$ under constant 335 light. Growth was determined by measurement of optical density at $750 \mathrm{~nm}\left(\mathrm{OD}_{750}\right)$. 


\section{Microbial helpers allow cyanobacteria to thrive in ferruginous waters}

336 Table 1. Locus tags of ROS response proteins in the bacterial species in this study. None 337 contained Mn-catalase or $\mathrm{Ni}$-superoxide dismutase. "--" indicates no homolog in genome. 338 OxyR: hydrogen peroxide inducible gene activator; KatG: catalase-peroxidase (clade 1); KatE: 339 periplasmic catalase (clade 3); AhpC: alkyl hydroperoxide reductase; Dps/MrgA: DNA-binding 340 ferritin-like protein; BtuE: glutathione peroxidase; SitA and MntA: ABC-type $\mathrm{Mn}^{2+}$ transporters; 341 MntH: NRAMP-type MntH Mn ${ }^{2+}$ transporter. KatG cellular localization based on PSORTb (Yu 342 et al., 2010): C: cytoplasmic; U: unknown.

\begin{tabular}{|c|c|c|c|c|c|c|c|c|c|c|}
\hline Species & $\begin{array}{l}\text { Locus } \\
\text { prefix }\end{array}$ & $\begin{array}{c}\text { OxyR } \\
\text { or } \\
\text { PerR }\end{array}$ & KatG & KatE & AhpC & $\begin{array}{c}\text { Dps/ } \\
\text { MrgA }\end{array}$ & BtuE & MntA & SitA & MntH \\
\hline $\begin{array}{c}\text { Synecho- } \\
\text { coccus } \\
\text { PCC } 7002\end{array}$ & $\begin{array}{c}\text { SYN } \\
\text { PCC } \\
\text { 7002_A }\end{array}$ & 1836 & $2422^{\mathrm{C}}$ & - & 0558 & 0031 & 0117 & 1734 & 2501 & - \\
\hline $\begin{array}{c}\text { Shewanella } \\
\text { baltica } \\
\text { OS155 }\end{array}$ & Sbal_ & 1181 & $0875^{\mathrm{C}}$ & 0894 & 0849 & 3285 & 1384 & - & - & 0678 \\
\hline $\begin{array}{c}\text { Shewanella } \\
\text { algae } \\
\text { MN-01 }\end{array}$ & AMR44 & 05180 & $\begin{array}{l}15815^{\mathrm{U}} \\
20550^{\mathrm{C}}\end{array}$ & 04925 & RS11285 & $\begin{array}{c}\text { RS07 } \\
720\end{array}$ & 08935 & 一 & - & 05235 \\
\hline $\begin{array}{c}\text { Shewanella } \\
\text { loihica } \\
\text { PV-4 }\end{array}$ & Shew_ & 1035 & $0709^{\mathrm{U}}$ & 3190 & 0792 & - & 2741 & - & - & 2965 \\
\hline $\begin{array}{c}\text { Shewanella } \\
\text { oneidensis } \\
\text { MR-1 }\end{array}$ & $\mathrm{SO}_{-}$ & 1328 & $\begin{array}{l}0725^{\mathrm{U}} \\
4405^{\mathrm{C}}\end{array}$ & 1070 & 0958 & 1158 & $\begin{array}{l}1563 \\
3349 \\
\end{array}$ & - & - & - \\
\hline $\begin{array}{c}\text { Shewanella } \\
\text { algae } \\
\text { BrY }\end{array}$ & BFS86_ & 05230 & $17460^{\mathrm{U}}$ & 16195 & 00635 & $\begin{array}{c}\text { RS11 } \\
070\end{array}$ & 19140 & - & - & - \\
\hline
\end{tabular}




\section{Microbial helpers allow cyanobacteria to thrive in ferruginous waters}
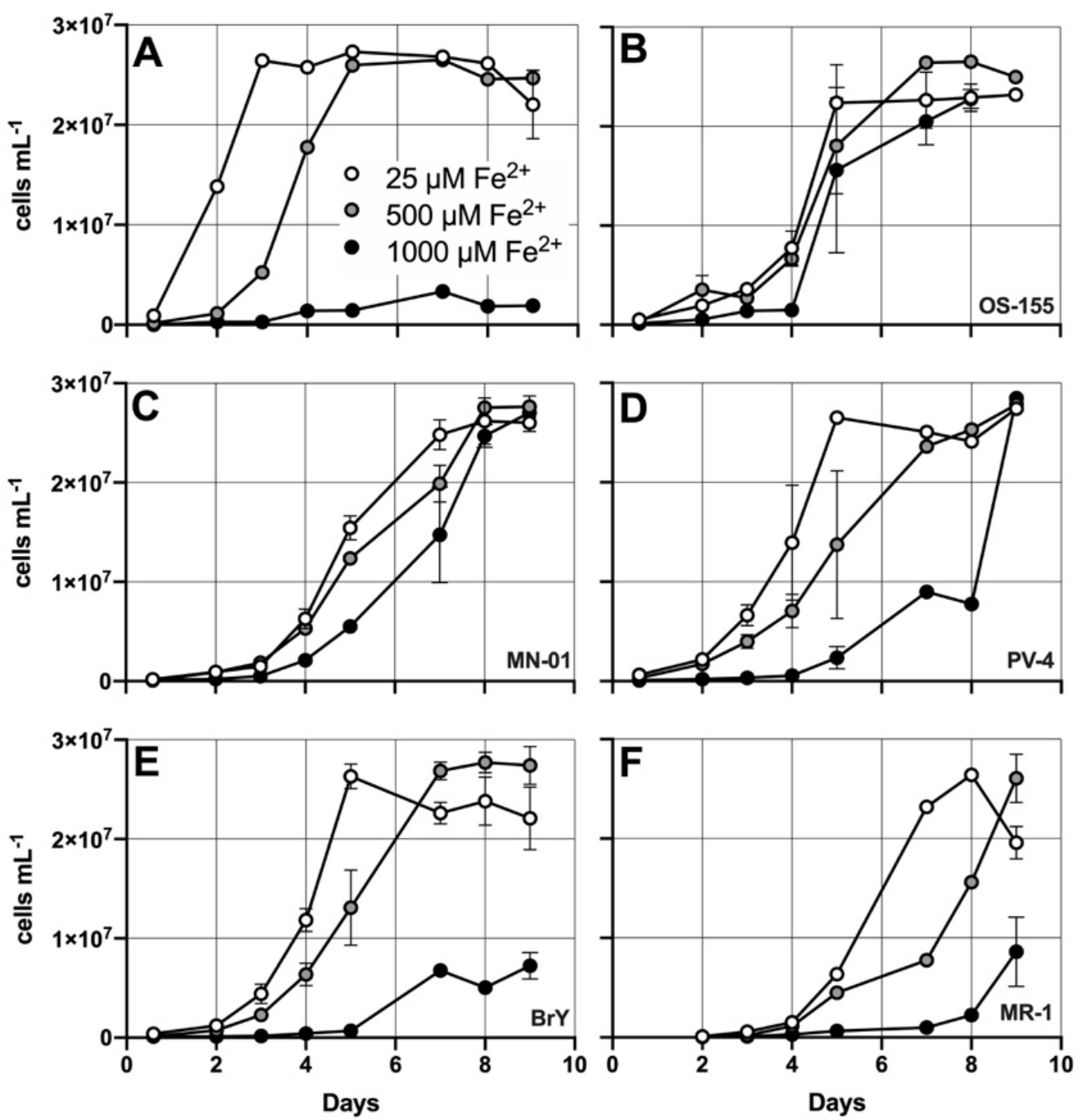

Figure 1. Growth of Synechococcus PCC 7002 in mono- or co-culture with Shewanella spp. with varying $\mathbf{F e}^{2+}$. Co-cultures are: A) none, B) Shewanella baltica OS-155, C) Shewanella algae MN-01, D) Shewanella loihica PV-4, E) Shewanella algae BrY, F) Shewanella oneidensis MR-1. Error bars represent the standard error of the mean $(n=3)$. 


\section{Microbial helpers allow cyanobacteria to thrive in ferruginous waters}
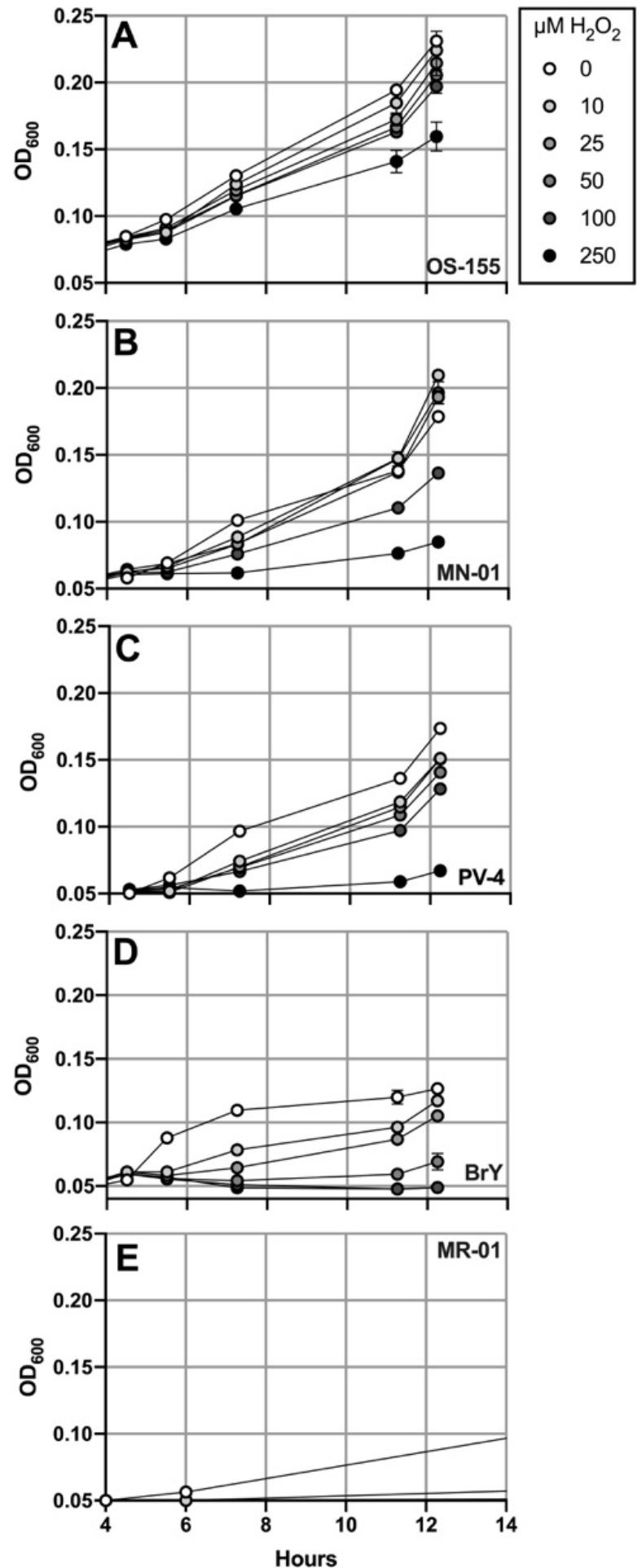

Figure 2. Growth of Shewanella spp. with varying $\mathbf{H}_{2} \mathbf{O}_{2}$. A) Shewanella baltica OS-155, B) except $S$. baltica OS-155, $\mathrm{n}=2$ ). $\mathrm{H}_{2} \mathrm{O}_{2}$ was added at the four-hour timepoint. 
Microbial helpers allow cyanobacteria to thrive in ferruginous waters

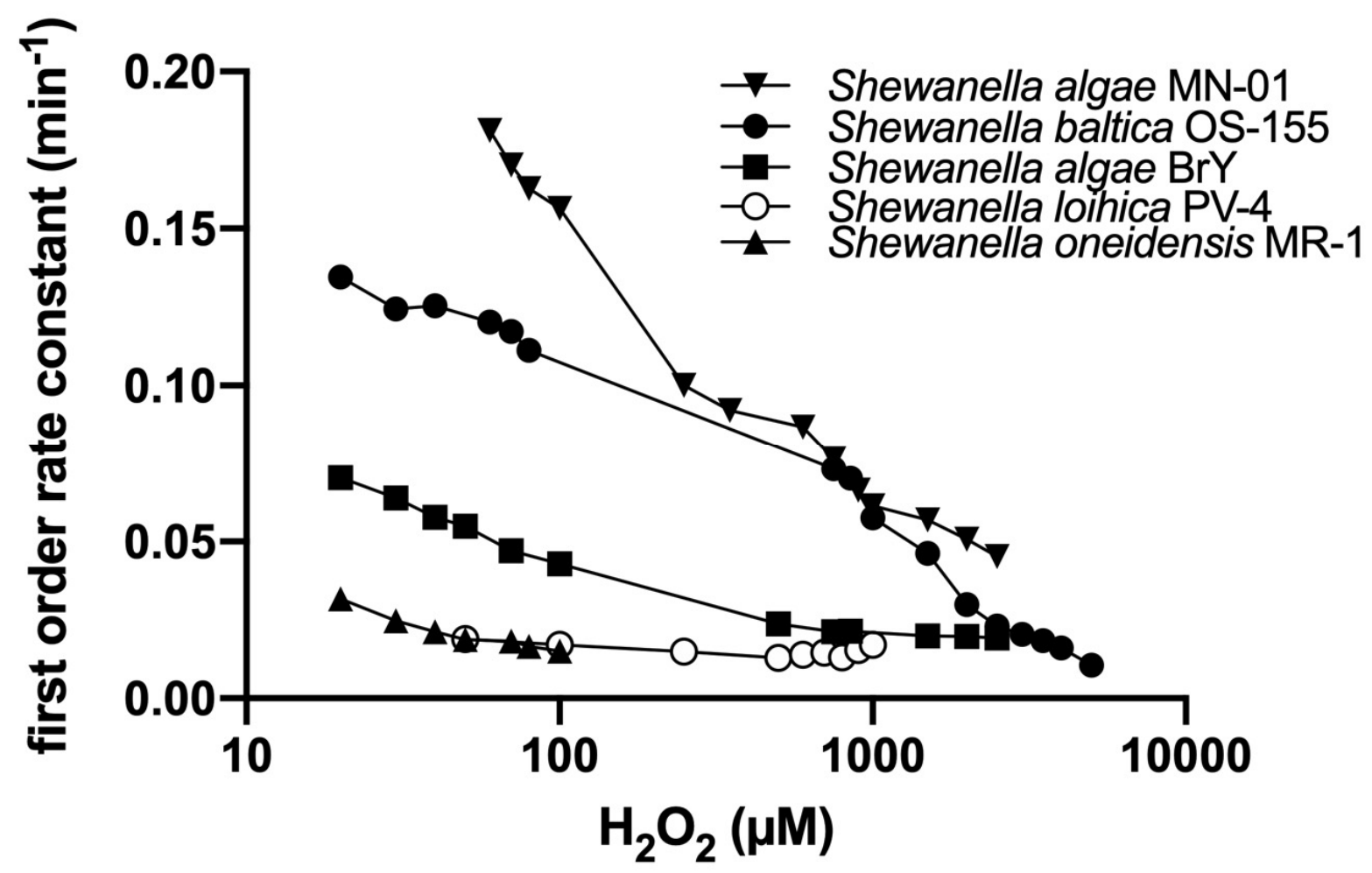

Figure 3. $\mathrm{H}_{2} \mathrm{O}_{2}$ peroxide scavenging capacity of Shewanella spp. shown as the first order rate constant plotted versus initial $\mathrm{H}_{2} \mathrm{O}_{2}$ concentration. No change in $\mathrm{H}_{2} \mathrm{O}_{2}$ was observed in the abiotic control. 


\section{Microbial helpers allow cyanobacteria to thrive in ferruginous waters}

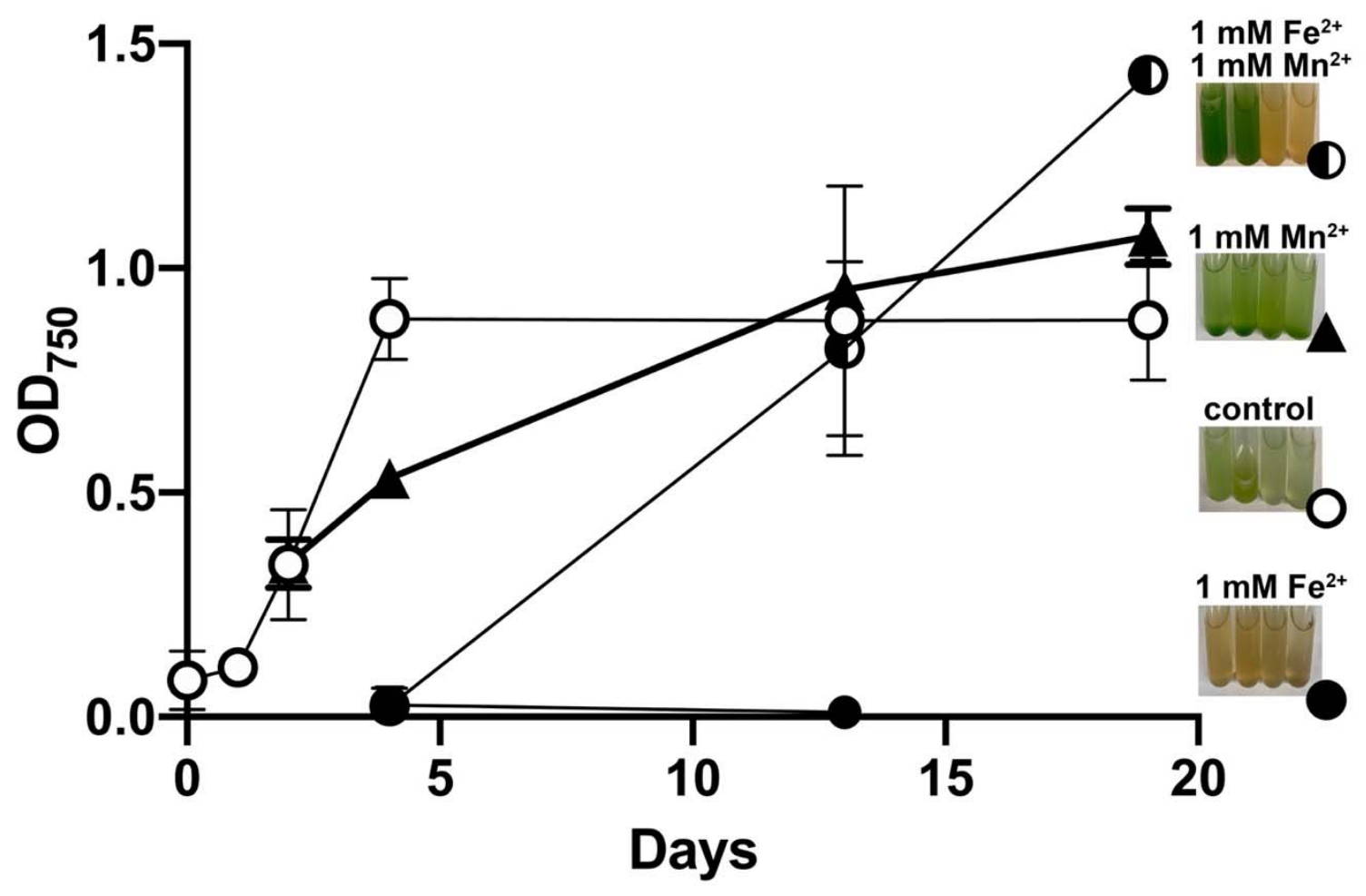

Figure 4. Growth of Synechococcus sp. PCC 7002 in monoculture with $1 \mathrm{mM} \mathrm{Fe} \mathrm{Fe}^{2+}$ and/or 1 $\mathbf{m M ~} \mathbf{M n}^{2+}$. Controls had background levels of $\sim 140 \mu \mathrm{M} \mathrm{Fe}^{2+}$ and $\sim 220 \mu \mathrm{M} \mathrm{Mn}^{2+}$. The growth curve for the $1 \mathrm{mM} \mathrm{Fe}{ }^{2+}+1 \mathrm{mM} \mathrm{Mn}^{2+}$ treatment is shown for the two replicates (out of four) that grew. Photos were taken on day 13. 
bioRxiv preprint doi: https://doi.org/10.1101/2020.05.08.085001; this version posted January 1, 2021. The copyright holder for this preprint (which was not certified by peer review) is the author/funder, who has granted bioRxiv a license to display the preprint in perpetuity. It is made available under aCC-BY-ND 4.0 International license.

\section{Microbial helpers allow cyanobacteria to thrive in ferruginous waters}

\section{Supplemental tables}

370 Table S1. Cyanobacterial genomes containing MnKat, KatE, or KatG. Appended as separate 371 spreadsheet. Shewanella loihica PV-4. Appended as separate spreadsheet. 
bioRxiv preprint doi: https://doi.org/10.1101/2020.05.08.085001; this version posted January 1, 2021. The copyright holder for this preprint (which was not certified by peer review) is the author/funder, who has granted bioRxiv a license to display the preprint in perpetuity. It is made available under aCC-BY-ND 4.0 International license.

\section{Microbial helpers allow cyanobacteria to thrive in ferruginous waters}

\section{References}

Aguirre, J. D., \& Culotta, V. C. (2012). Battles with iron: manganese in oxidative stress protection. Journal of Biological Chemistry, 287, 13541-13548.

Anjem, A., Varghese, S., \& Imlay, J. A. (2009). Manganese import is a key element of the OxyR response to hydrogen peroxide in Escherichia coli. Molecular Microbiology, 72, 844-858.

Archibald, F. S., \& Fridovich, I. (1982). The scavenging of superoxide radical by manganous complexes: in vitro. Archives of Biochemistry and Biophysics, 214, 452-463.

Ballal, A., Chakravarty, D., Bihani, S. C., \& Banerjee, M. (2020). Gazing into the remarkable world of non-heme catalases through the window of the cyanobacterial Mn-catalase 'KatB'. Free Radical Biology and Medicine, 160, 480-487.

Banerjee, M., Ballal, A., \& Apte, S. K. (2012). Mn $\square$ catalase (Alr0998) protects the photosynthetic, nitrogen $\square$ fixing cyanobacterium Anabaena PCC7120 from oxidative stress. Environmental Microbiology, 14, 2891-2900.

Bar-On, Y. M., Phillips, R., \& Milo, R. (2018). The biomass distribution on Earth. Proceedings of the National Academy of Sciences, 115, 6506-6511.

Barnese, K., Gralla, E. B., Valentine, J. S., \& Cabelli, D. E. (2012). Biologically relevant mechanism for catalytic superoxide removal by simple manganese compounds. Proceedings of the National Academy of Sciences, 109, 6892-6897.

Battistuzzi, F. U., Feijao, A., \& Hedges, S. B. (2004). A genomic timescale of prokaryote evolution: insights into the origin of methanogenesis, phototrophy, and the colonization of land. BMC Evolutionary Biology, 4.

Beliaev, A. S., Romine, M. F., Serres, M., Bernstein, H. C., Linggi, B. E., Markillie, L. M., Isern, N. G., Chrisler, W. B., Kucek, L. A., Hill, E. A., Pinchuk, G. E., Bryant, D. A., Wiley, H. S., Fredrickson, J. K., \& Konopka, A. (2014). Inference of interactions in cyanobacterialheterotrophic co-cultures via transcriptome sequencing. The ISME Journal, 8, 2243-2255.

Ben Said, S., \& Or, D. (2017). Synthetic microbial ecology: engineering habitats for modular consortia. Frontiers in Microbiology, 8, 1125.

Bernroitner, M., Zamocky, M., Furtmüller, P. G., Peschek, G. A., \& Obinger, C. (2009). Occurrence, phylogeny, structure, and function of catalases and peroxidases in cyanobacteria. Journal of Experimental Botany, 60, 423-440.

Bihani, S. C., Chakravarty, D., \& Ballal, A. (2016). KatB, a cyanobacterial Mn-catalase with unique active site configuration: Implications for enzyme function. Free Radical Biology and Medicine, 93, 118-129.

Biller, S. J., Coe, A., \& Chisholm, S. W. (2016). Torn apart and reunited: impact of a heterotroph on the transcriptome of Prochlorococcus. The ISME Journal, 10, 2831-2843.

Blank, C. E., \& Sanchez-Baracaldo, P. (2010). Timing of morphological and ecological innovations in the cyanobacteria - a key to understanding the rise in atmospheric oxygen. Geobiology, 8, 1-23.

Braakman, R., Follows, M. J., \& Chisholm, S. W. (2017). Metabolic evolution and the self-organization of ecosystems. Proceedings of the National Academy of Sciences, 114, E3091-E3100.

Brown, I. I., Bryant, D. A., Casamatta, D., Thomas-Keprta, K. L., Sarkisova, S. A., Shen, G., Graham, J. E., Boyd, E. S., Peters, J. W., \& Garrison, D. H. (2010). Polyphasic characterization of a thermotolerant siderophilic filamentous cyanobacterium that produces intracellular iron deposits. Applied and Environmental Microbiology, 76, 6664-6672.

Brown, I. I., Mummey, D., \& Cooksey, K. E. (2005). A novel cyanobacterium exhibiting an elevated tolerance for iron. FEMS Microbiology Ecology, 52, 307-314.

Canfield, D. E. (2005). The early history of atmospheric oxygen: homage to Robert M. Garrels. Annual Review of Earth and Planetary Sciences, 33, 1-36.

Canfield, D. E., Rosing, M. T., \& Bjerrum, C. (2006). Early anaerobic metabolisms. Philosophical Transactions of the Royal Society of London. Series B, Biological Sciences, 361, 1819-1836. 
bioRxiv preprint doi: https://doi.org/10.1101/2020.05.08.085001; this version posted January 1,2021. The copyright holder for this preprint (which was not certified by peer review) is the author/funder, who has granted bioRxiv a license to display the preprint in perpetuity. It is made available under aCC-BY-ND 4.0 International license.

\section{Microbial helpers allow cyanobacteria to thrive in ferruginous waters}

427

428

429

430

431

432

433

434

435

436

437

438

439

440

441

442

443

444

445

446

447

448

449

450

451

452

453

454

455

456

457

458

459

460

461

462

463

464

465

466

467

468

469

470

471

472

473

474

475

476

Cardona, T., Sánchez-Baracaldo, P., Rutherford, A. W., \& Larkum, A. W. (2019). Early Archean origin of Photosystem II. Geobiology, 17, 127-150.

Catling, D. C., Zahnle, K. J., \& Mckay, C. P. (2001). Biogenic methane, hydrogen escape, and the lirreversible oxidation of early Earth. Science, 293, 839-843.

Cavalier-Smith, T. (2006a). Cell evolution and Earth history: stasis and revolution. Philosophical Transactions of the Royal Society of London. Series B, Biological Sciences, 361, 969-1006.

Cavalier-Smith, T. (2006b). Rooting the tree of life by transition analyses. Biology Direct, 1, 19.

Chakravarty, D., Banerjee, M., Bihani, S. C., \& Ballal, A. (2016). A salt-inducible Mn-catalase (KatB) protects cyanobacterium from oxidative stress. Plant Physiology, 170, 761-773.

Chen, H., Xu, G., Zhao, Y., Tian, B., Lu, H., Yu, X., Xu, Z., Ying, N., Hu, S., \& Hua, Y. (2008). A novel OxyR sensor and regulator of hydrogen peroxide stress with one cysteine residue in Deinococcus radiodurans. PLoS ONE, 3, e1602.

Chen, M.-Y., Teng, W.-K., Zhao, L., Hu, C.-X., Zhou, Y.-K., Han, B.-P., Song, L.-R., \& Shu, W.-S. (2020). Comparative genomics reveals insights into cyanobacterial evolution and habitat adaptation. The ISME Journal, 1-17.

Cheton, P. L., \& Archibald, F. S. (1988). Manganese complexes and the generation and scavenging of hydroxyl free radicals. Free Radical Biology and Medicine, 5, 325-333.

Chisholm, S. W. (2017). Prochlorococcus. Current Biology, 27, R447-R448.

Christie-Oleza, J. A., Sousoni, D., Lloyd, M., Armengaud, J., \& Scanlan, D. J. (2017). Nutrient recycling facilitates long-term stability of marine microbial phototroph-heterotroph interactions. Nature Microbiology, 2, 17100.

Corno, G., Villiger, J., \& Pernthaler, J. (2013). Coaggregation in a microbial predator-prey system affects competition and trophic transfer efficiency. Ecology, 94, 870-881.

Cremer, J., Melbinger, A., Wienand, K., Henriquez, T., Jung, H., \& Frey, E. (2019). Cooperation in microbial populations: theory and experimental model systems. Journal of Molecular Biology, 431, 4599-4644.

Daly, M. J., Gaidamakova, E. K., Matrosova, V., Vasilenko, A., Zhai, M., Venkateswaran, A., Hess, M., Omelchenko, M., Kostandarithes, H. M., \& Makarova, K. (2004). Accumulation of Mn (II) in Deinococcus radiodurans facilitates gamma-radiation resistance. Science, 306, 1025-1028.

Derry, L. A. (2015). Causes and consequences of mid-Proterozoic anoxia. Geophysical Research Letters, $42,8538-8546$.

Drever, J. (1974). Geochemical model for the origin of Precambrian banded iron formations. GSA Bulletin, 85, 1099-1106.

Fischer, W. W., Hemp, J., \& Valentine, J. S. (2016). How did life survive Earth's great oxygenation? Current Opinion in Chemical Biology, 31, 166-178.

Goldenfeld, N., \& Woese, C. (2011). Life is physics: Evolution as a collective phenomenond far from equilibrium. Annual Review of Condensed Matter Physics, 2, 375-399.

Hajam, I. A., Dar, P. A., Shahnawaz, I., Jaume, J. C., \& Lee, J. H. (2017). Bacterial flagellin—a potent immunomodulatory agent. Experimental \& Molecular Medicine, 49, e373-e373.

Hamilton, T. L. (2019). The trouble with oxygen: The ecophysiology of extant phototrophs and implications for the evolution of oxygenic photosynthesis. Free Radical Biology and Medicine, 140, 233-249.

Hamilton, T. L., Bryant, D. A., \& Macalady, J. L. (2016). The role of biology in planetary evolution: cyanobacterial primary production in low-oxygen Proterozoic oceans. Environmental Microbiology, 18, 325-340.

Hanaoka, Y., Takebe, F., Nodasaka, Y., Hara, I., Matsuyama, H., \& Yumoto, I. (2013). Growthdependent catalase localization in Exiguobacterium oxidotolerans T-2-2T reflected by catalase activity of cells. PLoS ONE, 8, e76862.

Hansel, C. M. (2017). Manganese in marine microbiology. In: Advances in Microbial Physiology. Elsevier, pp. 37-83. 
bioRxiv preprint doi: https://doi.org/10.1101/2020.05.08.085001; this version posted January 1,2021. The copyright holder for this preprint (which was not certified by peer review) is the author/funder, who has granted bioRxiv a license to display the preprint in perpetuity. It is made available under aCC-BY-ND 4.0 International license.

\section{Microbial helpers allow cyanobacteria to thrive in ferruginous waters}

Hansel, C. M., \& Diaz, J. M. (2020). Production of extracellular reactive oxygen species by marine biota. Annual Review of Marine Science, 13.

Haqq-Misra, J., Kasting, J. F., \& Lee, S. (2011). Availability of O2 and H2O2 on pre-photosynthetic Earth. Astrobiology, 11, 293-302.

Hernandez, M. E., Kappler, A., \& Newman, D. K. (2004). Phenazines and Other Redox-Active Antibiotics Promote Microbial Mineral Reduction. Applied and Environmental Microbiology, 70, 921-928.

Herrmann, A. J., \& Gehringer, M. M. (2019). An investigation into the effects of increasing salinity on photosynthesis in freshwater unicellular cyanobacteria during the late Archaean. Geobiology, 17, 343-359.

Hill, E. A., Chrisler, W. B., Beliaev, A. S., \& Bernstein, H. C. (2017). A flexible microbial co-culture platform for simultaneous utilization of methane and carbon dioxide from gas feedstocks. Bioresource Technology, 228, 250-256.

Holland, H. D. (1973). The Oceans; A Possible Source of Iron in Iron-Formations. Economic Geology, $68,1169-1172$.

Holland, H. D. (1984). The chemical evolution of the atmosphere and oceans, Princeton University Press.

Holland, H. D. (2002). Volcanic gases, black smokers, and the great oxidation event. Geochimica et Cosmochimica Acta, 66, 3811-3826.

Holland, H. D. (2009). Why the atmosphere became oxygenated: A proposal. Geochimica et Cosmochimica Acta, 73, 5241-5255.

Horsburgh, M. J., Wharton, S. J., Karavolos, M., \& Foster, S. J. (2002). Manganese: elemental defence for a life with oxygen. Trends in Microbiology, 10, 496-501.

Imlay, J. A. (2003). Pathways of oxidative damage. Annual Reviews in Microbiology, 57, 395-418.

Imlay, J. A. (2008). Cellular defenses against superoxide and hydrogen peroxide. Annual Review of Biochemistry, 77, 755-776.

Imlay, J. A. (2013). The molecular mechanisms and physiological consequences of oxidative stress: lessons from a model bacterium. Nature Reviews Microbiology, 11, 443-454.

Ionescu, D., Buchmann, B., Heim, C., Häusler, S., De Beer, D., \& Polerecky, L. (2014). Oxygenic photosynthesis as a protection mechanism for cyanobacteria against iron-encrustation in environments with high Fe2+ concentrations. Frontiers in Microbiology, 5, 459.

Jiang, Y., Dong, Y., Luo, Q., Li, N., Wu, G., \& Gao, H. (2014). Protection from oxidative stress relies mainly on derepression of OxyR-dependent KatB and Dps in Shewanella oneidensis. Journal of Bacteriology, 196, 445-458.

Johnson, J. E., Webb, S. M., Ma, C., \& Fischer, W. W. (2016). Manganese mineralogy and diagenesis in the sedimentary rock record. Geochimica et Cosmochimica Acta, 173, 210-231.

Johnston, D. T., Wolfe-Simon, F., Pearson, A., \& Knoll, A. H. (2009). Anoxygenic photosynthesis modulated Proterozoic oxygen and sustained Earth's middle age. Proceedings of the National Academy of Sciences, 106, 16925-16929.

Kehres, D. G., Janakiraman, A., Slauch, J. M., \& Maguire, M. E. (2002). Regulation of Salmonella enterica serovar Typhimurium $m n t H$ transcription by $\mathrm{H} 2 \mathrm{O} 2, \mathrm{Fe} 2+$, and $\mathrm{Mn} 2+$. Journal of Bacteriology, 184, 3151-3158.

Kendall, B., Reinhard, C. T., Lyons, T. W., Kaufman, A. J., Poulton, S. W., \& Anbar, A. D. (2010). Pervasive oxygenation along late Archaean ocean margins. Nature Geoscience, 3, 647-652.

Khademian, M., \& Imlay, J. A. (2020). How microbes evolved to tolerate oxygen. Trends in Microbiology.

Klotz, M. G., \& Loewen, P. C. (2003). The molecular evolution of catalatic hydroperoxidases: evidence for multiple lateral transfer of genes between prokaryota and from bacteria into eukaryota. Molecular Biology and Evolution, 20, 1098-1112.

Komiya, T., Hirata, T., Kitajima, K., Yamamoto, S., Shibuya, T., Sawaki, Y., Ishikawa, T., Shu, D., Li, Y., \& Han, J. (2008). Evolution of the composition of seawater through geologic time, and its influence on the evolution of life. Gondwana Research, 14, 159-174. 
bioRxiv preprint doi: https://doi.org/10.1101/2020.05.08.085001; this version posted January 1,2021. The copyright holder for this preprint (which was not certified by peer review) is the author/funder, who has granted bioRxiv a license to display the preprint in perpetuity. It is made available under aCC-BY-ND 4.0 International license.

\section{Microbial helpers allow cyanobacteria to thrive in ferruginous waters}

528

529

530

531

532

533

534

535

536

537

538

539

540

541

542

543

544

545

546

547

548

549

550

551

552

553

554

555

556

557

558

559

560

561

562

563

564

565

566

567

568

569

570

571

572

573

574

575

576

577

Konhauser, K. O., Lalonde, S. V., Planavsky, N. J., Pecoits, E., Lyons, T. W., Mojzsis, S. J., Rouxel, O. J., Barley, M. E., Rosìere, C., Fralick, P. W., Kump, L. R., \& Bekker, A. (2011). Aerobic bacterial pyrite oxidation and acid rock drainage during the Great Oxidation Event. Nature, 478, 369-373.

Lalonde, S. V., \& Konhauser, K. O. (2015). Benthic perspective on Earth's oldest evidence for oxygenic photosynthesis. Proceedings of the National Academy of Sciences, 112, 995-1000.

Latifi, A., Ruiz, M., \& Zhang, C.-C. (2009). Oxidative stress in cyanobacteria. FEMS Microbiology Reviews, 33, 258-278.

Latour, J.-M. (2015). Manganese, the stress reliever. Metallomics, 7, 25-28.

Lee, Yeung, L. Y., Mckenzie, N. R., Yokoyama, Y., Ozaki, K., \& Lenardic, A. (2016). Two-step rise of atmospheric oxygen linked to the growth of continents. Nature Geoscience, 9, 417.

Li, H., Singh, A. K., Mcintyre, L. M., \& Sherman, L. A. (2004). Differential gene expression in response to hydrogen peroxide and the putative PerR regulon of Synechocystis sp. strain PCC 6803. Journal of Bacteriology, 186, 3331-3345.

Liu, W., Hao, J., Elzinga, E. J., Piotrowiak, P., Nanda, V., Yee, N., \& Falkowski, P. G. (2020). Anoxic photogeochemical oxidation of manganese carbonate yields manganese oxide. Proceedings of the National Academy of Sciences, 117, 22698-22704.

Luo, G., Ono, S., Beukes, N. J., Wang, D. T., Xie, S., \& Summons, R. E. (2016). Rapid oxygenation of Earth's atmosphere 2.33 billion years ago. Science Advances, 2, e1600134.

Lyons, T. W., Reinhard, C. T., \& Planavsky, N. J. (2014). The rise of oxygen in Earth's early ocean and atmosphere. Nature, 506, 307-315.

Martin, W. F., Bryant, D. A., \& Beatty, J. T. (2018). A physiological perspective on the origin and evolution of photosynthesis. FEMS Microbiology Reviews, 42, 205-231.

Mishra, S., \& Imlay, J. (2012). Why do bacteria use so many enzymes to scavenge hydrogen peroxide? Archives of Biochemistry and Biophysics, 525, 145-160.

Morris, J. J., Johnson, Z. I., Szul, M. J., Keller, M., \& Zinser, E. R. (2011). Dependence of the cyanobacterium Prochlorococcus on hydrogen peroxide scavenging microbes for growth at the ocean's surface. PLoS ONE, 6, e16805.

Morris, J. J., Kirkegaard, R., Szul, M. J., Johnson, Z. I., \& Zinser, E. R. (2008). Facilitation of robust growth of Prochlorococcus colonies and dilute liquid cultures by "helper" heterotrophic bacteria. Applied and Environmental Microbiology, 74, 4530-4534.

Myers, C. R., \& Nealson, K. H. (1988). Bacterial manganese reduction and growth with manganese oxide as the sole electron acceptor. Science, 240, 1319-1321.

Olson, S. L., Kump, L. R., \& Kasting, J. F. (2013). Quantifying the areal extent and dissolved oxygen concentrations of Archean oxygen oases. Chemical Geology, 362, 35-43.

Ossa Ossa, F., Hofmann, A., Wille, M., Spangenberg, J. E., Bekker, A., Poulton, S. W., Eickmann, B., \& Schoenberg, R. (2018). Aerobic iron and manganese cycling in a redox-stratified Mesoarchean epicontinental sea. Earth and Planetary Science Letters, 500, 28-40.

Ozaki, K., Thompson, K. J., Simister, R. L., Crowe, S. A., \& Reinhard, C. T. (2019). Anoxygenic photosynthesis and the delayed oxygenation of Earth's atmosphere. Nature Communications, 10, 3026.

Özkaya, Ö., Xavier, K. B., Dionisio, F., \& Balbontín, R. (2017). Maintenance of microbial cooperation mediated by public goods in single- and multiple-trait scenarios. Journal of Bacteriology, 199, e00297-00217.

Papp-Wallace, K. M., \& Maguire, M. E. (2006). Manganese transport and the role of manganese in virulence. Annual Reviews in Microbiology, 60, 187-209.

Partensky, F., \& Garczarek, L. (2010). Prochlorococcus: advantages and limits of minimalism. Annual Review of Marine Science, 2, 305-331.

Planavsky, N. J., Asael, D., Hofmann, A., Reinhard, C. T., Lalonde, S. V., Knudsen, A., Wang, X., Ossa Ossa, F., Pecoits, E., Smith, A. J. B., Beukes, N. J., Bekker, A., Johnson, T. M., Konhauser, K. 
bioRxiv preprint doi: https://doi.org/10.1101/2020.05.08.085001; this version posted January 1,2021. The copyright holder for this preprint (which was not certified by peer review) is the author/funder, who has granted bioRxiv a license to display the preprint in perpetuity. It is made available under aCC-BY-ND 4.0 International license.

\section{Microbial helpers allow cyanobacteria to thrive in ferruginous waters}

O., Lyons, T. W., \& Rouxel, O. J. (2014). Evidence for oxygenic photosynthesis half a billion years before the Great Oxidation Event. Nature Geoscience, 7, 283-286.

Reinhard, C. T., Lalonde, S. V., \& Lyons, T. W. (2013a). Oxidative sulfide dissolution on the early Earth. Chemical Geology, 362, 44-55.

Reinhard, C. T., Planavsky, N. J., \& Lyons, T. W. (2013b). Long-term sedimentary recycling of rare sulphur isotope anomalies. Nature, 497, 100-103.

Rodríguez Amor, D., \& Dal Bello, M. (2019). Bottom-up approaches to synthetic cooperation in microbial communities. Life, 9, 22.

Sánchez-Baracaldo, P. (2015). Origin of marine planktonic cyanobacteria. Scientific Reports, 5, 17418.

Sánchez $\square$ Baracaldo, P., \& Cardona, T. (2020). On the origin of oxygenic photosynthesis and Cyanobacteria. New Phytologist, 225, 1440-1446.

Sekar, R., Shin, H. D., \& Dichristina, T. J. (2016). Direct conversion of cellulose and hemicellulose to fermentable sugars by a microbially-driven Fenton reaction. Bioresource Technology, 218, 11331139.

Shcolnick, S., Summerfield, T. C., Reytman, L., Sherman, L. A., \& Keren, N. (2009). The mechanism of iron homeostasis in the unicellular cyanobacterium Synechocystis sp. PCC 6803 and its relationship to oxidative stress. Plant Physiology, 150, 2045-2056.

Smethurst, D. G., Kovalev, N., Mckenzie, E. R., Pestov, D. G., \& Shcherbik, N. (2020). Iron-mediated degradation of ribosomes under oxidative stress is attenuated by manganese. Journal of Biological Chemistry, 295, 17200-17214.

Sobota, J. M., \& Imlay, J. A. (2011). Iron enzyme ribulose-5-phosphate 3-epimerase in Escherichia coli is rapidly damaged by hydrogen peroxide but can be protected by manganese. Proceedings of the National Academy of Sciences, 108, 5402-5407.

Song, H., Jiang, G., Poulton, S. W., Wignall, P. B., Tong, J., Song, H., An, Z., Chu, D., Tian, L., She, Z., $\&$ Wang, C. (2017). The onset of widespread marine red beds and the evolution of ferruginous oceans. Nature Communications, 8, 399.

Stadtman, E., Berlett, B., \& Chock, P. (1990). Manganese-dependent disproportionation of hydrogen peroxide in bicarbonate buffer. Proceedings of the National Academy of Sciences, 87, 384-388.

Stevens Jr., S. E., Patterson, C. O. P., \& Myers, J. (1973). The production of hydrogen peroxide by bluegreen algae: a survey. Journal of Phycology, 9, 427-430.

Swanner, E. D., Mloszewska, A. M., Cirpka, O. A., Schoenberg, R., Konhauser, K. O., \& Kappler, A. (2015a). Modulation of oxygen production in Archaean oceans by episodes of $\mathrm{Fe}$ (II) toxicity. Nature Geoscience, 8, 126-130.

Swanner, E. D., Wu, W., Hao, L., Wüstner, M. L., Obst, M., Moran, D. M., Mcilvin, M. R., Saito, M. A., \& Kappler, A. (2015b). Physiology, Fe(II) oxidation, and Fe mineral formation by a marine planktonic cyanobacterium grown under ferruginous conditions. Frontiers in Earth Science, 3.

Wan, F., Kong, L., \& Gao, H. (2018). Defining the binding determinants of Shewanella oneidensis OxyR: implications for the link between the contracted OxyR regulon and adaptation. Journal of Biological Chemistry, 293, 4085-4096.

Wang, Y., \& Newman, D. K. (2008). Redox reactions of phenazine antibiotics with ferric (hydr)oxides and molecular oxygen. Environmental Science \& Technology, 42, 2380-2386.

Ward, L. M., Idei, A., Nakagawa, M., Ueno, Y., Fischer, W. W., \& Mcglynn, S. E. (2019). Geochemical and metagenomic characterization of Jinata Onsen, a Proterozoic-analog hot spring, reveals novel microbial diversity including iron-tolerant phototrophs and thermophilic lithotrophs. Microbes and Environments, ME19017.

Ward, L. M., Idei, A., Terajima, S., Kakegawa, T., Fischer, W. W., \& Mcglynn, S. E. (2017). Microbial diversity and iron oxidation at Okuoku $\square$ hachikurou Onsen, a Japanese hot spring analog of Precambrian iron formations. Geobiology, 15, 817-835.

Yu, N. Y., Wagner, J. R., Laird, M. R., Melli, G., Rey, S., Lo, R., Dao, P., Sahinalp, S. C., Ester, M., \& Foster, L. J. (2010). PSORTb 3.0: improved protein subcellular localization prediction with 


\section{Microbial helpers allow cyanobacteria to thrive in ferruginous waters}

628

629

630

631

632

633

634

635

636

637

638

639

640

641

642

643

644 refined localization subcategories and predictive capabilities for all prokaryotes. Bioinformatics, 26, 1608-1615.

Zamocky, M., Furtmuller, P. G., \& Obinger, C. (2008). Evolution of catalases from bacteria to humans. Antioxidants \& Redox Signaling, 10, 1527-1548.

Zamocky, M., Gasselhuber, B., Furtmuller, P. G., \& Obinger, C. (2012). Molecular evolution of hydrogen peroxide degrading enzymes. Archives of Biochemistry and Biophysics, 525, 131-144.

Zhou, M., Diwu, Z., Panchuk-Voloshina, N., \& Haugland, R. P. (1997). A stable nonfluorescent derivative of resorufin for the fluorometric determination of trace hydrogen peroxide: applications in detecting the activity of phagocyte NADPH oxidase and other oxidases. Analytical Biochemistry, 253, 162-168.

Zinser, E. R. (2018a). Cross-protection from hydrogen peroxide by helper microbes: the impacts on the cyanobacterium Prochlorococcus and other beneficiaries in marine communities. Environmental Microbiology Reports, 10, 399-411.

Zinser, E. R. (2018b). The microbial contribution to reactive oxygen species dynamics in marine ecosystems. Environmental Microbiology Reports, 10, 412-427. 